\title{
Clinical and Basic Scientific Implications of Cell Migration and Microchimerism After Organ Transplantation
}

\author{
Thomas E. Starzl \\ Department of Surgery, University of Pittsburgh, Pittsburgh, Pennsylvania, U.S.A.
}

Whole organ transplantation practices have brought this form of surgical treatment to a high level of efficiency and success, contrary to the pessimistic predictions at the outset of most immunologists. Historically, an allograft was envisioned as defenseless and vulnerable to immunologic attack in proportion to its histocompatibility disparity with that of the recipient. This dogma defined transplantation in terms of a unidirectional immune reaction both for bone marrow and organs (a one-way paradigm) (Fig. 1).

The one-way paradigm was unchallenged for more than 3 decades until in 1992, we discovered the presence of ubiquitous low level donor leukocyte chimerism in our human organ recipients as long as 30 years posttransplantation $(1,2)$. We postulated from these findings (and subsequently obtained much confirmatory evidence [3-5]) that the interaction of 2 coexisting donor and recipient leukocyte populations, each to the other, was the generic mechanism of successful tolerance after bone marrow transplantation as well as the acceptance of organ allografts (Fig. 2).

The phenomenology of microchimerism has been widely verified in experimental models. The mutual cancelling effect of the coexisting cell populations explains the blurring of a major histocompatibility complex (MHC) matching effect on the outcome of organ transplantation, the ability to transplant histoincompatible liver, intestine, and bone marrow to the noncytoablated recipient without causing graftversus-host disease (GVHD), and the ability to stop immunosuppression in many organ recipients $(1,2,6)$. Most importantly, this concept provides a fresh con-

Received July 1997

Address correspondence and reprint requests to Dr. Thomas E. Starzl, University of Pittsburgh, Department of Surgery, 4 West Falk Clinic, 3601 5th Avenue, Pittsburgh, PA 15213, U.S.A.

Presented in part at the XIth World Congress of the International Society for Artificial Organs, held June 29-July 1, 1997, in Providence, Rhode Island, U.S.A. text to exploit basic immunologic information in xenotransplantation and other initiatives.

This 2-way (bidirectional) paradigm has been under intense examination because it has mandated reexamination of transplantation immunology at every level. First, the 2-way paradigm established the long sought linkage between the whole organ transplant practices that were evolved empirically and the neonatal acquired immunologic tolerance originally described more than 40 years ago by Billingham, Brent, and Medawar $(7,8)$. The discoveries of spontaneous chimerism gave startling insight into what was actually being accomplished with whole organ transplantation, allowing a revision of historic context.

More importantly, these discoveries have illuminated the future (9). The mechanisms leading to chimerism and governing allograft acceptance also ultimately determine the outcome after xenotransplantation. Although it will be difficult to first breech the humoral barrier, manipulating the individual limbs of the 2-way reaction (host versus graft and graft versus host) is expected to be the key to the ultimate successful use of animal organs in humans.

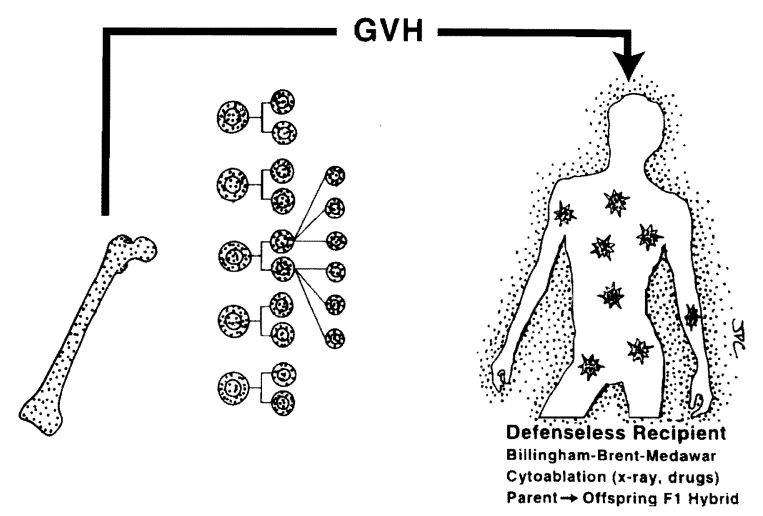

FIG. 1. Shown is the one-way paradigm in which transplantation is conceived as involving a unidirectional immune reaction: hostversus-graft (HVG) with whole organs and graft-versus-host (GVH) with bone marrow or other lymphopoietic transplants. 


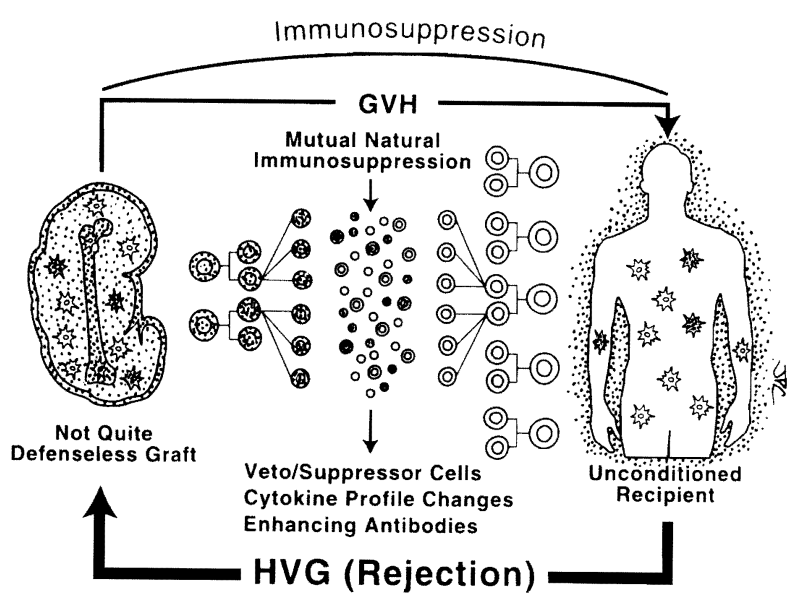

FIG. 2. Shown is the two-way paradigm in which transplantation is seen as a bidirectional and mutually cancelling immune reaction that is predominantly HVG with whole organ grafts and predominantly GVH with bone marrow grafts.

\section{REFERENCES}

1. Starzl TE, Demetris AJ, Murase N, Ildstad S, Ricordi C, Trucco M. Cell migration, chimerism, and graft acceptance. Lancet 1992;339:1579-82.
2. Starzl TE, Demetris AJ, Trucco M, Murase N, Ricordi C, Ildstad S, Ramos H, Todo S, Tzakis A, Fung JJ, Nalesnik M, Rudert WA, Kocova M. Cell migration and chimerism after whole organ transplantation: The basis of graft acceptance. Hepatology 1993;17:1127-52.

3. Demetris AJ, Murase N, Fujisaki S, Fung JJ, Rao AS, Starzl TE. Hematolymphoid cell trafficking, microchimerism, and GVHD reactions after liver, bone marrow, and heart transplantation. Transplant Proc 1993;25:3337-44.

4. Qian S, Demetris AJ, Murase N, Rao AS, Fung JJ, Starzl TE. Murine liver allograft transplantation: Tolerance and donor cell chimerism. Hepatology 1994;19:916-24.

5. Murase N, Starzl TE, Tanabe M, Fujisaki S, Miyazawa H, Ye Q, Delaney CP, Fung JJ, Demetris AJ. Variable chimerism, graft versus host disease, and tolerance after different kinds of cell and whole organ transplantation from Lewis to BrownNorway rats. Transplantation 1995;60:158-71.

6. Starzl TE, Demetris AJ, Murase N, Thomson AW, Trucco M, Ricordi C. Donor cell chimerism permitted by immunosuppressive drugs: A new view of organ transplantation. Immunol Today 1993;14:326-32.

7. Billingham RE, Brent L, Medawar PB. "Actively acquired tolerance" of foreign cells. Nature 1953;172:603-6.

8. Billingham R, Brent L, Medawar P. Quantitative studies on tissue transplantation immunity. III. Actively acquired tolerance. Philos Trans R Soc Lond (Biol) 1956;239:357-412.

9. Starzl TE, Valdivia LA, Murase N, Demetris AJ, Fontes P, Rao AS, Manez R, Marino I, Todo S, Thomson AW, Fung JJ. The biologic basis of and strategies for clinical xenotransplantation. Immunol Rev 1994;141:213-44. 